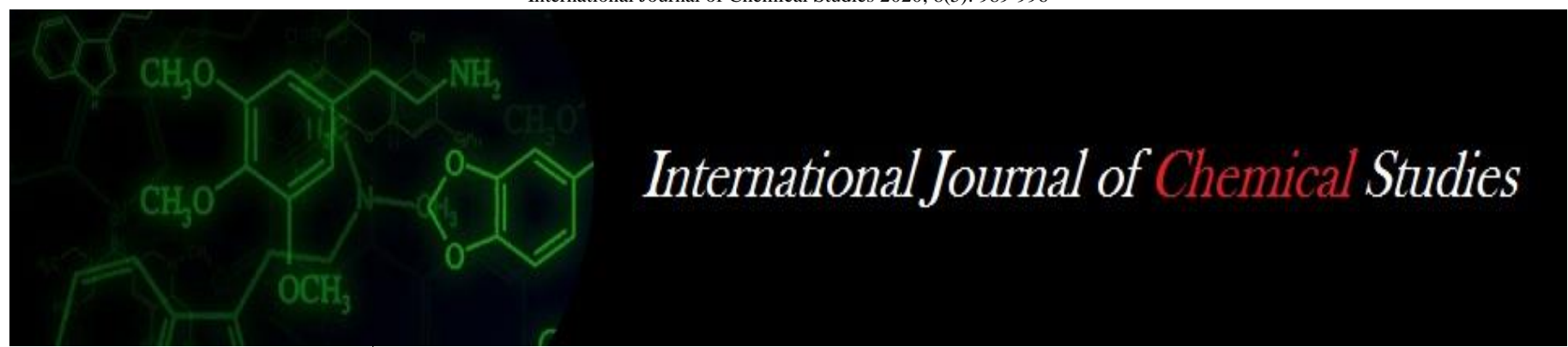

P-ISSN: 2349-8528

E-ISSN: 2321-4902

www.chemijournal.com

IJCS 2020; 8(5): 989-996

(C) 2020 IJCS

Received: 20-06-2020

Accepted: 15-08-2020

Anurag Patel

Ph.D., Student, Vaugh Institute of Agricultural Engineering and Technology, SHUATS,

Prayagraj, Uttar Pradesh, India

RC Singh

Principal Scientist, ICAR-

Central Institute of Agricultural

Engineering, Bhopal, Madhya

Pradesh, India

Ashok Tripathi

Professor and Head, Vaugh

Institute of Agricultural

Engineering and Technology,

SHUATS, Prayagraj, Uttar

Pradesh, India
Corresponding Author:

Anurag Patel

Ph.D., Student, Vaugh Institute of Agricultural Engineering and

Technology, SHUATS,

Prayagraj, Uttar Pradesh, India

\section{Development and testing of tractor operated variable depth fertilizer applicator on application of granular urea in wheat crop planted on beds}

\author{
Anurag Patel, RC Singh and Ashok Tripathi
}

DOI: https://doi.org/10.22271/chemi.2020.v8.i5n.10426

\begin{abstract}
High fertilizer rate and labor requirement are common problems in traditional application of fertilizer. Fertilizer applicator was tested and evaluated for wheat crop (Triticumaestivum) planted on bed cultivation system. Study included suitable measurement techniques for recording various field parameters. Physical properties of granular urea fertilizer have been studied such as size and shape, sphericity, moisture content $18.7 \%$, bulk density $0.76 \mathrm{~g} / \mathrm{m}^{3}$ and hundred particles weight $0.8 \mathrm{gm}$. The machine was calibrated in the laboratory for different rate of fertilizer application and determination of coefficient of variation. The field tests of machine were conducted on the wheat crop planted on bed in 5 rows. Operating parameters such as operational speed $3.7 \mathrm{~km} / \mathrm{h}$, wheel slippage $4.69 \%$, average field capacity $0.65 \mathrm{ha} / \mathrm{h}$, field efficiency $80.10 \%$ and plant damage $4.33 \%$ were found respectively. Crop and Straw yield were found for three fertilizer application methods broadcast5.72 t/ha, $5.38 \mathrm{t} / \mathrm{ha}$,foliar application6.1 t/ha and $15.82 \mathrm{t} /$ haand tractor operated fertilizer applicator $15.89 \mathrm{t} / \mathrm{ha}, 16.5 \mathrm{t} / \mathrm{ha}$. The tractor operated variable depth fertilizer applicator resulted $3 \%$ and $6.5 \%$ increase in yield as compared to broadcast and foliar application. Because in this method ammonia did not evaporate to the atmosphere due to placing of fertilizer at a depth of $100 \mathrm{~mm}$ below the soil surface. The saving of fertilizer by placing it in the soil by tractor operated fertilizer applicator was 33.33 and $16.6 \mathrm{~kg} / \mathrm{ha}$ as compared to broadcast and foliar methods, which leads to saving of Rs 341 and Rs 611/ha respectively.
\end{abstract}

Keywords: Wheat crop, tractor operated, fertilizer applicator, broadcast and foliar application

\section{Introduction}

Tractor operated variable depth fertilizer applicator for application of granular urea at the root zone of wheat plants. Was introduced in the country for its useful to meet the growing needs of the farmers with high level of production and productivity and increase the use efficiency of urea. Top dressing of Nitrogen to the wheat crops results emission of nitrogen gas to the atmosphere and placement is not in the proper root zone thus to reduce the loss of nitrogen in to atmosphere and increased the utilization efficiency, research work is needed for the placement of nitrogen in to the root zone of plants to avoid the nitrogen emission to the atmosphere and increase the use efficiency of nitrogen. For maximum efficiency of applied fertilizer, it is essential to deliver nutrients to the root zone of plants at a rate which is sufficient for maximum uptake while avoiding fixation with clay particles. The attention should, therefore, be given towards addition of fertilizers in subsoil to increase its nutritive status. In situations where deep loosening is required, the incorporation of fertilizer had been found to be beneficial (Godwin and Spoor, 1981) ${ }^{[9]}$ as compare to spreading of nitrogenous fertilizer in the field, that loss about $30 \% \mathrm{~N}$ to the atmosphere.

India is second largest producer of wheat in the world, averaging an annual production of 65,856 MT. On average, India consumes 65,283 MT of wheat, ranking second largest consumer of wheat in the world. On average, India imports 990 MT of wheat, and for various reasons, exports an average of 767 MT of wheat. The ending stocks in India average 9,900 MT, giving India the third largest ending stocks in the world. The major winter wheat growing areas in India are located in the northern regions of the country. The state of Uttar Pradesh produces the most wheat in India, accounting for 35 percent of India's total wheat production. Following on Punjab producing 22 percent of the nation's total wheat production. 
The sowing of winter wheat begins from October and runs through the end of December, with harvest following in March and May.

The world today uses around 83 MT of N, which is about a 100 fold increase over the last 100 years. About $60 \%$ of global $\mathrm{N}$ fertilizer is used for producing the world's three major cereals: rice, wheat, and maize. While India uses many types of fertilizers, urea accounts for most of the consumption of $\mathrm{N}$ and DAP for most of that of $\mathrm{P}_{2} \mathrm{O}_{5}$. Urea accounts for 82 percent of the total consumption of straight $\mathrm{N}$ fertilizers.

Rowse and Stone 1980.Studied the reduction and application of the $\mathrm{N}$ content to the soil. Only 40 to $50 \%$ of $\mathrm{N}$ fertilizers, 20 to $30 \%$ of $\mathrm{P}$ and $\mathrm{K}$ fertilizers were effectively used by crops while the remaining become volatilized, leached to groundwater, or get fixed within the soil as per the properties of their contents. Contrary to this loss, the basal application of fertilizers using planters and seed-drills have been found to be effective, but application of fertilizers even by these methods does not distribute fertilizers evenly as per the needs of roots and therefore, more research works are needed to be done on these aspects.

Wuest and Cassman 1992.Found recovery of $\mathrm{N}$ applied at planting ranged from 30 to $55 \%$, while recovery of $\mathrm{N}$ applied at anthesis ranged from 55 to $80 \%$ in irrigated wheat. The amount of fertilizer $\mathrm{N}$ applied at anthesis had the greatest influence on post-anthesis $\mathrm{N}$ uptake, which ranged from 17 to $77 \mathrm{~kg} \mathrm{~N} / \mathrm{ha}$. This showed that late $\mathrm{N}$ application can be efficiently taken up by plants. Grain protein levels may increase with late-season $\mathrm{N}$ applications. Fertilizer $\mathrm{N}$ use efficiency varied considerably depending upon the native soil $\mathrm{N}$ supply, previous $\mathrm{N}$ uptake, developmental stage of the plant when supplemental $\mathrm{N}$ was applied, and yield potential. Optimizing fertilizer $\mathrm{N}$ use, achieving acceptable grain yield, and maintaining adequate grain protein required knowledge of expected $\mathrm{N}$ uptake efficiency and utilization within the plant in relation to the rate and timing of $\mathrm{N}$ applied.

Yang et al. 2001 [17]. Studied variable rates application of nitrogenous $(\mathrm{N})$ and phosphorus $(\mathrm{P})$ fertilizer for grain sorghum. The results showed that VRT increased yield, reduce yield variability, and raised economic returns. VRT was effective in reducing the input of $\mathrm{N}$ fertilizer; however, the causes and effects were complex. The fertilization method did not influence crop responses to $\mathrm{P}$ fertilizer. However, VRF resulted in better $\mathrm{P}$ fertilizer management because it applied 12 to $41 \%$ less fertilizer and reduced soil-test $\mathrm{P}$ variability compared with the conventional injection fertilization method. Koch (2004) assessed the economic feasibility of variable rate nitrogen application and found that variable-rate $\mathrm{N}$ application utilizing site-specific management zones were more economically feasible than conventional and uniform $\mathrm{N}$ application.

Blackshaw et al. $2004^{[2]}$. He found investigated the effect of nitrogen fertilization application in simulating wheat (Triticum aestivum) yield loss caused by wild oat (Avenafatua) interference. Fertilizer application could affect the biomass of wild oat in spring wheat. Although the little information to assess the effect of fertilizer application on wheat yield loss due to wild oat interference. The knowledge of the effect of $\mathrm{N}$ fertilization on weed population dynamics might be use full for recommending the most convenient method and stage of the crop cycle for fertilizer application to both increase the crop yield and reduce the growth rates of weed populations.

Nitrogen (N) loss from winter wheat plants has been identified but has not been simultaneously evaluated for several genotypes grown under different $\mathrm{N}$ fertility. Two field experiments were initiated in 1993 and 1994 at the Agronomy Research Station in Desai, R.M. and C.R. Bhatia, 1978to estimate plant $\mathrm{N}$ loss from several cultivars as a function of $\mathrm{N}$ applied and to characterize $\mathrm{N}$ use efficiency (NUE). A total of five cultivars were evaluated at preplant $\mathrm{N}$ rates ranging from 30 to $180 \mathrm{~kg}$ ha. Nitrogen loss was estimated as the difference between total forage $\mathrm{N}$ accumulated at anthesis and the total $($ grain + straw) $\mathrm{N}$ at harvest. Forage, grain, straw yield, $\mathrm{N}$ uptake, and $\mathrm{N}$ loss increased with increasing $\mathrm{N}$ applied at both Stillwater and Perkins. Significant differences were observed among varieties for yield, $\mathrm{N}$ uptake, $\mathrm{N}$ loss and components of NUE in forage, grain, straw and grain + straw. Estimates of $\mathrm{N}$ loss over this two year period ranged from 4.0 to $27.9 \mathrm{~kg}$ ha (7.7 to $59.4 \%$ of total forage $\mathrm{N}$ at anthesis). Most $\mathrm{N}$ losses occurred between anthesis and 14 days post-anthesis. Avoiding excess $\mathrm{N}$ application would reduce $\mathrm{N}$ loss and increase NUE in winter wheat varieties. Varieties with high harvest index (grain yield/total biomass) and low forage yield had low plant $\mathrm{N}$ loss.

The application of fertilizers is usually accomplished by methods such as manual spreading, broadcasting, placement or mixing in upper soil layer of $20-50 \mathrm{~mm}$ only. Broadcasting of fertilizers, especially $\mathrm{P}$ and $\mathrm{K}$, produces fixation problems due to more soil contact, whereas volatilization of $\mathrm{N}$ results in reduction of applied $\mathrm{N}$ content to the soil. Only 40 to $50 \%$ of $\mathrm{N}$ fertilizers, 20 to $30 \%$ of $\mathrm{P}$ and $\mathrm{K}$ fertilizers are effectively used by crops while the remaining become volatilized, leached to groundwater, or get fixed within the soil as per the properties of their contents (Olsen et al., 1971). Contrary to this loss, the basal application of fertilizers using planters and seed-drills have been found to be effective, but application of fertilizers even by these methods does not distribute fertilizers evenly as per the needs of roots. Fertilizer application technology use to place the fertilizer under the soil near root zone of plants has the potential to increase crop yields and soil and water quality relative to broad casting. Application of fertilizer inside the soil surface increases the utilization efficiency of fertilizer and reduces the emission of $\mathrm{N}$ to the atmosphere. The various types of equipment and technology available for fertilizer application are also discussed.

\section{Materials and Methods}

The fertilizer applicator machine together with testing and performance evaluation of application of fertilizer (Urea) on bed planted wheat crop. It also includes suitable measurement techniques for recording various parameters related to performance evaluation of machine under the laboratory and field condition. The properties of fertilizer (granular urea) used in the experiment were determined for efficient metering the application rate of fertilizer. Machine was calibrated in the laboratory for different rates of fertilizer application and determination of coefficient of variation. The field tests of machine were conducted on the wheat crop planted on beds and its performance parameters were recorded. For efficient metering of fertilizer by the machine, the physical properties such as shape, size, sphericity, and weight of granular urea were determined in the laboratory

The machine parameter of the frame and row to row spacing between tines were considered according to wheat crop and fertilizer application between rows. For the tine and furrow opener, soil type, soil resistance, working soil moisture and bulk density of black soil were considered as main factors. The sectional strength of these components were selected such as they were able to work at soil depth varying from 50 - 
$300 \mathrm{~mm}$. Machine componentare main frame, fertilizer box, fertilizer metering system, shank furrow openers and ground drive wheel.

Table 1: Fertilizer applicator machine component and materials

\begin{tabular}{|c|c|c|}
\hline $\begin{array}{c}\text { S. } \\
\text { No. }\end{array}$ & Machine parts & Materials \\
\hline 1. & Frame & Mild steel \\
\hline 2. & Hitching system & MS flat \\
\hline 3. & Fertilizer box & Angle iron, MS sheet \\
\hline 4. & Fertilizer adjustment lever & Mild steel \\
\hline 5. & Fertilizer metering system & $\begin{array}{c}\text { Die casted aluminum } \\
\text { (BIS: } 6816 \text { part } 1973 \text { ) }\end{array}$ \\
\hline 6. & Fertilizer metering drive mechanism & Mild steel, Chain, Gear \\
\hline 7. & Fertilizer tube & Transparent plastic pipe \\
\hline 8. & Furrow opener & $\begin{array}{c}\text { Mild steel, MS pipe, MS } \\
\text { plate, MS sheet }\end{array}$ \\
\hline 9. & Ground wheel & $\begin{array}{c}\text { Mild steel, MS flats, MS } \\
\text { rod }\end{array}$ \\
\hline
\end{tabular}

Table 2: Machine Specification are given below.

\begin{tabular}{|c|c|c|}
\hline S. No. & Particulars & Dimension \\
\hline 1. & All dimension of Machine LxWxH, mm & $1850 \mathrm{x} \mathrm{1645x} \mathrm{1258}$ \\
\hline 2. & Weight of Machine, $\mathrm{kg}$ & 126 \\
\hline 3. & Capacity,ha/h & 0.65 \\
\hline 4. & Speed, $\mathrm{km} / \mathrm{h}$ & 3.7 \\
\hline 5. & Power requirement (tractor), hp & 35 \\
\hline 6. & Depth of application of fertilizer, $\mathrm{mm}$ & $100-150$ \\
\hline 7. & Row spacing of crop, $\mathrm{mm}$ & 225 \\
\hline
\end{tabular}

\section{Laboratory and field testing}

Machine was calibrated for application of grannular urea at $60.2 \mathrm{~kg} / \mathrm{ha}$ and $130 \mathrm{~kg} / \mathrm{ha}$ to provide 30 and $60 \mathrm{~kg} \mathrm{~N} / \mathrm{ha}$ in wheat crop. The following steps were followed for calibration of fertilizer applicator.

\section{Machine Calibration}

a. Diameter of the ground drive wheel was measured to calculate circumference of wheel.

b. Area covered in one revolution of the drive wheel was calculated.

c. The calibration was done for 20 revolution of the drive wheel; therefore, the area delivered in 20 revolution of the wheel was calculated from the area covered by 20 revolution of drive wheel.

d. The rate control adjustment for the fertilizer was set for maximum dropping.

e. The fertilizer dropped in polythene bags attached with each furrow opener was weighed separately and total weight of fertilizer was calculated.

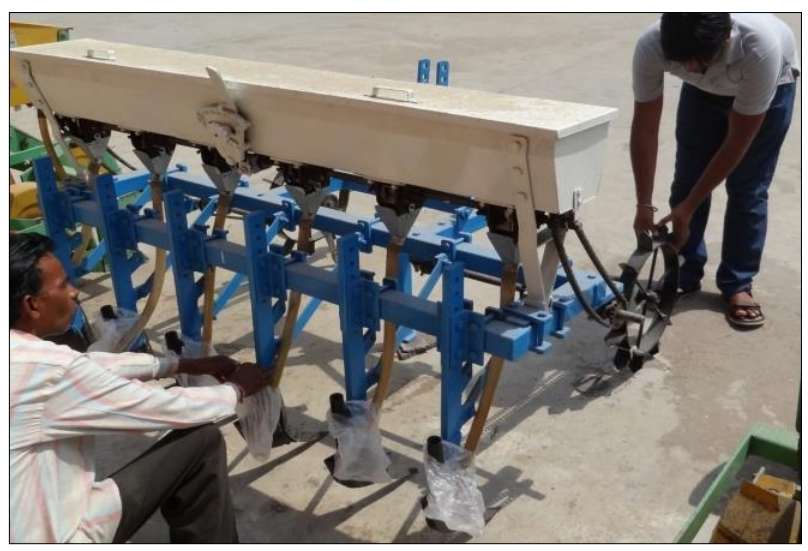

Fig 1: Calibration of fertilizer applicator in the laboratory

\section{Coefficient of uniformity}

The uniformity is proper distribution pattern of fertilizer particles from the outlet in longitudinal direction of travel of machine. It was calculated by using equation (1)

$\mathrm{Cu}=100(1-\Sigma \mathrm{X} / \mathrm{m} \mathrm{n})$

\section{Where}

$\mathrm{Cu}=$ Coefficient of uniformity in percent, $\mathrm{m}=$ mean value of all observations $\mathrm{g}$, $\mathrm{n}=$ total number of observations,

$\mathrm{X}=$ numerical deviation of individual observation from the mean application rate $\mathrm{g}$,

\section{Soil and Machine parameter}

Table 3: Type and character of soil are reported.

\begin{tabular}{|c|c|c|}
\hline S. No. & Particulars & Value \\
\hline 1. & Texture, $\%$ & $\begin{array}{c}\text { Gravel: } 7.12 ; \text { Sand: } \\
\text { Silt: Clay: } 14.79: \\
30.51: 54.70\end{array}$ \\
\hline 2. & Porosity, $\%$ & 41.90 \\
\hline 3. & Field capacity at 0.3 bar, $\%$ & 30.86 \\
\hline 4. & $\begin{array}{c}\text { Percolation rate of saturated non } \\
\text { puddle soil, mm/day }\end{array}$ & 9.80 \\
\hline 5. & pH & 7.94 \\
\hline 6. & Structure & Sub angular blocky \\
\hline 7. & Safe bearing capacity of soil, $\mathrm{t} / \mathrm{m}^{2}$ & 11 \\
\hline 8. & Soil depth & More than one meter \\
\hline 9. & Type of soil & black (vertisol) \\
\hline
\end{tabular}

\section{Moisture content}

For measurement of soil moisture, core sample of wet soils were taken in three different locations of test plots selected randomly. Samples were weighed in a physical balance and weight of each wet soil sample was recorded. Samples were placed in a hot air oven maintained at $105^{\circ} \mathrm{C}$ for at least 8 hours. At the end of 8 hours, samples were cooledin desiccators and weighed in a physical balance. Soil moisture (\% dry weight basis)was calculated using the formula given below.

Soil moisture content $=$

$\frac{\text { Weight of wet soil sample-Weight of oven dry soil sample }}{\text { Weight of oven dry soil sample }} \times 100 \ldots$

\section{Where}

$\mathrm{Mw}=$ Moisture content on dry weight basis\%

$\mathrm{Wm}=$ Soil weight of moisture sample, $\mathrm{g}$,

Ws $=$ Soil weight of oven dry sample, $g$.

\section{Bulk density}

For measuring of bulk density of soil. Core samples of soil were obtained from three locations selected randomly in the test plot. The diameter and length of cylindrical soil sample was measured. The core samples were kept in a hot air oven maintained at $105^{\circ} \mathrm{c}$ for at least 8 hours. At the end of 8 hour, the samples were taken out from the oven and cooledin desiccators. Cuter samples wereand weigh in a physical balance and the bulk density was calculated by using equation ${ }^{[7]}$.

Bulk density of soil $=\frac{\mathrm{M}}{\mathrm{V}}$

\section{Where}

$\mathrm{M}=$ oven dry mass contained in core sample, $\mathrm{g}$ $\mathrm{V}=$ volume of cylinder core sampler, $\mathrm{cm}^{3}$ 


\section{Cone index}

Cone index is an indication of soil hardness and is expressed as force per square centimeter required for a cone to penetrate into soil. Cone index is the same soil varies with cone apex angle and area of cone bottom. An apex angle and area or diameter of cone used should be given in the report. The cone index of soil was recorded by using a dial type cone penetrometer have apex angle $30^{\circ}$ and dia $50 \mathrm{~mm}$.

\section{Field testing of machine}

The machine was evaluated for placement of granular urea at depth of $100 \& 150 \mathrm{~mm}$ in wheat crop. During the test following parameter were recorded.

\section{Speed of operation}

The speed of operation was determined by recording the average time required to cover $50 \mathrm{~m}$ length by the following formula.

Speed $(\mathrm{km} / \mathrm{h})=\frac{3.6 \times \text { distance travelled }(\mathrm{m})}{\text { Time }(\mathrm{s})}$

\section{Power requirement}

The power requirement was determined from draft and speed of operation using the following formula:

$\mathrm{Hp}=\frac{\operatorname{Draft}(\mathrm{kg}) \times \operatorname{Speed}(\mathrm{m} / \mathrm{min})}{4500}$

\section{Wheel Slippage}

To calculate the wheel slip the tractor was operated at implement with load and without load condition. A mark on the rear wheel was put to count the number of revolution. The distance traveled by the tractor is 10 revolution of tractor rear wheel was measured and wheel slip was calculated as follows [6].

wheel slippage $\%=\frac{\mathrm{N} 1-\mathrm{N} 2}{\mathrm{~N} 1} \times 100$

\section{Where}

$\mathrm{N} 1=$ No. of revolution of drive wheel for a given distance under load.

N2 = No. of revolution of drive wheel for the same distance at no load.

\section{Field capacity and field efficiency}

The effective field capacity, theoretical field capacity and field efficiency were calculated by recording the time consumed for actual work and time lost for other miscellaneous activities such as turning, adjustments under field operating condition. The field capacity was calculated by using the following equations and efficiency.

Effectivefieldcapacity $(S)=\frac{A}{T_{P}+T_{1}}$

\section{Where}

$\mathrm{S}=$ Effective field capacity, ha/ha

$\mathrm{A}=$ Area covered, ha

$\mathrm{Tp}=$ Productive time, $\mathrm{hr}$

$\mathrm{Tl}=$ Non-productive time, $\mathrm{hr}$.

Theoretical field capacity $(\mathrm{ha} / \mathrm{h})=\frac{\mathrm{W} \times \mathrm{S}}{10}$

\section{Where}

$\mathrm{S}=$ Speed of operation, $(\mathrm{km} / \mathrm{h})$

$\mathrm{W}=$ Theoretical width covered, $(\mathrm{m})$

$=$ no. of furrow opener multiplied by distance between two consecutive furrow opener.

$$
\begin{aligned}
& \text { Field efficiency }=\frac{\text { Effective field capacity }}{\text { Theoretical field capacity }} \\
& \qquad E_{f}=\frac{W_{e} \times V_{e} \times T_{p}}{W_{t} \times V_{t} \times\left(T_{p} \times T_{l}\right)} 100
\end{aligned}
$$

\section{Where}

$\mathrm{E}_{\mathrm{f}}=$ field efficiency, $\%$

$\mathrm{W}_{\mathrm{e}}=$ Effective working width

$\mathrm{W}_{\mathrm{t}}=$ Theoretical working width

$\mathrm{V}_{\mathrm{e}}=$ Effective operation speed

$\mathrm{V}_{\mathrm{t}}=$ Theoretical operation speed

$\mathrm{T}_{\mathrm{p}}=$ Productive time

$\mathrm{T}_{1}=$ Non-productive time .

\section{Fuel consumption}

The following simple method was used. The fuel tank was filled to full capacity before and after the test operation. Amount of refueling after the test is the fuel consumption for the test. When filling up the tank, careful attention was paid to keep the tank horizontal and not to leave empty space in the tank.

\section{Results and Discussion}

Physical properties of granular urea a tractor drawn fertilizer applicator was developed and tested in laboratory and field for application of urea on wheat crop sown on beds. The parameters obtained from the laboratory studies have been utilized for the field testing of machine in the field. Physical properties of fertilizer (granular urea) related to fertilizer applicator that have been studied included size and shape of granular urea were $1.82 \pm 0.4 \mathrm{~mm}, 1.84 \pm 0.4 \mathrm{~mm}, 1.85 \pm 0.4$ $\mathrm{mm}$ respectively. The sphericity of urea was $0.99 \pm 0.004 \%$. The moisture content of urea was $18.7 \%$.It indicated that the urea used in the experiment was almost round in shape. Mean values of shape and sphericity are summarized in Table 4. The bulk density of and of granular urea investigated was $0.76 \pm 0.0011 \mathrm{~g} / \mathrm{m}^{3}$ at moisture content of $18.7 \%$ granular urea Table 5 and the hundred particles weight of urea was $0.8 \pm 0.6$ at $18.7 \%$ moisture content of urea (Table 6) fertilizer mass (weight) of hundred particles.

Table 4: Axial dimensions (diameter) and sphericity of granular urea

\begin{tabular}{|c|c|c|c|c|}
\hline Particulars & \multicolumn{3}{|c|}{ Axial dimension (mm) } & Sphericity \\
\hline & $\mathrm{A}$ & $\mathrm{B}$ & $\mathrm{C}$ & \\
\hline Mean & 1.82 & 1.84 & 1.85 & 0.9908 \\
\hline S.E.(mean) & 0.202675 & 0.202082 & 0.206257 & 0.0026 \\
\hline 95 \% confidence limit & $1.82 \pm 0.4$ & $1.84 \pm 0.4$ & $1.85 \pm 0.4$ & $0.99 \pm 0.004$ \\
\hline
\end{tabular}

Table 5: Bulk density of the granular urea.

\begin{tabular}{|c|c|c|}
\hline Particular & Mass $(\mathbf{g m})$ & Density $\left(\mathbf{g m} / \mathbf{c m}^{\mathbf{3}}\right)$ \\
\hline Mean & 382.58 & 0.76 \\
\hline S.E. mean & 0.284839 & 0.00057 \\
\hline 95\% confidence limit & $382.58 \pm 0.56$ & $0.76 \pm 0.0011$ \\
\hline
\end{tabular}

Table 6: Hundred particles weight of granular urea.

\begin{tabular}{|c|c|c|}
\hline Mean, $\mathbf{g}$ & S.E. Mean & 95\% confidence limit \\
\hline 0.8 & 0.038944 & $0.8 \pm 0.6$ \\
\hline
\end{tabular}




\section{Calibration of fertilizer applicator}

The fertilizer applicator was calibrated for application of granular urea at the rate of $60.2 \mathrm{~kg} / \mathrm{ha}$ and $130.4 \mathrm{~kg} / \mathrm{ha}$ in the laboratory to provide the 30 and $60 \mathrm{~kg} \mathrm{~N} / \mathrm{ha} 20$ revolutions of ground drive wheel gave .00471 ha area. The fertilizer delivered in each tube of furrow opener was collected and weighed for three replications. Mean discharge rate and coefficients of variation of fertilizer application rate are shown in Table 7. The minimum and maximum quantities of fertilizer discharged from 20 revolution of ground drive wheel were 0.290 and $0.350 \mathrm{~kg}$. The average fertilizer discharge rate ranged from 0.034 to $0.046 \mathrm{~kg}$, in tube $1,0.042$ to $0.050 \mathrm{~kg}$ in tube $2,0.059$ to $0.069 \mathrm{~kg}$ in tube $3,0.034$ to $0.051 \mathrm{~kg}$ in tube 4, 0.081 to $0.085 \mathrm{~kg}$ in tube $5,0.038$ to $0.049 \mathrm{~kg}$ in tube 6 . The mean discharge rate of fertilizer from all the tubes ranged from 0.048 to $0.058 \mathrm{~kg}$ for 20 revolution of ground drive wheel, It resulted mean fertilizer application rate of 61.57 to $74.30 \mathrm{~kg} / \mathrm{ha}$. The Coefficient of variation for calibrated fertilizer application rate ranged from 2.6 to $3.9 \%$ among the all fertilizer tubes. It revealed that there was no significance difference for the fertilizer delivery rates among the tubes. Because, coefficient of variation is less than $5 \%$ level.

Table 7: Calibration of machine for fertilizer metering device urea $(60.2 \mathrm{~kg} / \mathrm{ha})$

\begin{tabular}{|c|c|c|c|c|c|c|c|c|c|c|c|}
\hline \multirow{2}{*}{ S. No. } & \multicolumn{10}{|c|}{ Discharge from the tube for 20 revolution of ground wheel } \\
\cline { 2 - 13 } & Tube 1 & Tube 2 & Tube 3 & Tube 4 & Tube 5 & Tube 6 & Application rate kg/ha & Mean discharge kg & S.D. & C.V. \\
\hline 1 & 0.046 & 0.05 & 0.069 & 0.051 & 0.085 & 0.049 & 74.30 & 0.0583 & 0.0154 & 0.026 \\
\hline 2 & 0.038 & 0.042 & 0.062 & 0.036 & 0.081 & 0.041 & 64.33 & 0.0500 & 0.0178 & 0.036 \\
\hline 3 & 0.034 & 0.043 & 0.059 & 0.034 & 0.082 & 0.038 & 61.57 & 0.0483 & 0.0189 & 0.039 \\
\hline Mean & 0.0393 & 0.045 & 0.0633 & 0.0403 & 0.0827 & 0.0427 & 66.7333 & -- & -- & --- \\
\hline S.D. & 0.0061 & 0.0044 & 0.0051 & 0.0093 & 0.0021 & 0.0057 & 6.6967 & --- & --- & $\cdots$ \\
\hline
\end{tabular}

Table 8: Calibration of machine for fertilizer metering device urea $(130.4 \mathrm{~kg} / \mathrm{ha})$

\begin{tabular}{|c|c|c|c|c|c|c|c|c|c|c|c|}
\hline \multirow{2}{*}{ S. No. } & \multicolumn{10}{|c|}{ Discharge from the tube for 20 revolution of ground wheel } \\
\cline { 2 - 13 } & Tube 1 & Tube 2 & Tube 3 & Tube 4 & Tube 5 & Tube 6 & Application rate kg/ha & Mean discharge kg & S.D. & C.V. \\
\hline 1 & 0.108 & 0.101 & 0.114 & 0.098 & 0.114 & 0.098 & 134.00 & 0.1057 & 0.0073 & 0.0695 \\
\hline 2 & 0.106 & 0.088 & 0.104 & 0.089 & 0.118 & 0.091 & 126.53 & 0.0993 & 0.0120 & 0.1207 \\
\hline 3 & 0.11 & 0.089 & 0.119 & 0.091 & 0.126 & 0.094 & 133.54 & 0.1048 & 0.0157 & 0.1499 \\
\hline Mean & 0.1140 & 0.0967 & 0.1223 & 0.0983 & 0.1243 & 0.1010 & 131.55 & --- & -- & --- \\
\hline S.D. & 0.0106 & 0.0142 & 0.0202 & 0.0145 & 0.0057 & 0.0148 & 4.3854 & --- & --- & --- \\
\hline
\end{tabular}

Similarly the fertilizer applicator was calibrated for grannular urea application rate of $130 \mathrm{~kg} / \mathrm{ha}$ in the laboratory by operating 20 revolutions of ground drive wheel. It gave 0.00471 ha area. The fertilizer delivered in each tube of furrow opener was collected and weighed for three replications. Mean discharge rate and coefficients of variation of fertilizer application rate are shown in Table 8. The minimum and maximum quantities of fertilizer discharge from 20 revolution of ground drive wheel were 0.596 and $0.745 \mathrm{~kg}$. The average fertilizer discharge rate ranged from 0.106 to $0.126 \mathrm{~kg}$ in tube $1,0.088$ to $0.113 \mathrm{~kg}$ in tube 2 , 0.0104 to $0.144 \mathrm{~kg}$ in tube $3,0.089$ to $0.115 \mathrm{~kg}$ in tube 4 , 0.118 to $0.129 \mathrm{~kg}$ in tube $5,0.091$ to $0.118 \mathrm{~kg}$ in tube 6 . The mean discharge rate of fertilizer from all the tubes ranged from 0.099 to $0.124 \mathrm{~kg}$ for 20 revolution of ground drive wheel, It resulted mean fertilizer application rate of 126.53 to $158.17 \mathrm{~kg} / \mathrm{ha}$. The coefficient of variation for calibrated fertilizer application rate ranged from 6.95 to $14.99 \%$ among the all fertilizer tubes. It revealed that there the fertilizer discharge rate below the specified limit of $20 \% \mathrm{CV}$ in the field resulted the uniformity application among the tubes. Because, coefficient of variation is less than $14.99 \%$ level.

\section{Field Performance}

The developed machine was tested in the field for application of granular urea on wheat crop sown on bed. The size of beds on which wheat crop was sown in 5 rows is given in Table 9. Moisture content, bulk density and cone index of experimental field is shown in Table 10. During the field trials of machine moisture content, bulk density and cone index of experimental field were $26.47 \%, 1.32 \mathrm{~g} / \mathrm{cc}$ and 0.79 $\mathrm{kg} / \mathrm{cm}^{2}$ at the depth of $0-100 \mathrm{~mm}$, respectively. The crop parameters recorded during the testing of machine as plant height nos. of plants and tillers are shown in Table 11.

Table 9: Size of experimental beds used for sowing of wheat crop.

\begin{tabular}{|c|c|c|c|c|c|c|}
\hline S. No. & Dimension of bed (size) & I & II & III & Mean & S. D. \\
\hline 1 & Top width, $\mathrm{mm}$ & 1200 & 1250 & 1230 & 1226.67 & 25.16 \\
\hline 2 & Bottom width, mm & 1630 & 1650 & 1640 & 1640 & 10.00 \\
\hline 3 & Height, $\mathrm{mm}$ & 162 & 201 & 152 & 171.67 & 25.89 \\
\hline
\end{tabular}

Table 10: Moisture content, bulk density and cone index of experimental field at depth 0-100 mm at standing crop.

\begin{tabular}{|c|c|c|c|}
\hline Depth of soil (0-10 cm) & Moisture content (\%) & Bulk density $\mathbf{g} / \mathbf{c c}$ & Cone index kg/cm \\
\hline T1 & 25.01 & 1.15 & 3.71 \\
\hline T2 & 26.68 & 1.43 & 4.50 \\
\hline T3 & 24.56 & 1.21 & 3.97 \\
\hline T4 & 29.66 & 1.52 & 3.45 \\
\hline Mean & 26.47 & 1.32 & 3.90 \\
\hline S. D. & 2.309 & 0.175 & 0.448 \\
\hline
\end{tabular}


Table 11: Crop parameter for wheat Varity HI-1544 sown

\begin{tabular}{|c|c|c|c|c|c|c|}
\hline S. No. & Particulars & I & II & III & Mean & S. D. \\
\hline 1 & Row spacing, mm & 224 & 222 & 225 & 223.67 & 1.53 \\
\hline 2 & Depth of application, mm & 140 & 149 & 150 & 146.33 & 5.51 \\
\hline 3 & Width of application, m & 1.5 & 1.5 & 1.5 & 1.5 & 0 \\
\hline 4 & No. of plant/m ${ }^{2}$ at 21 DAS. & 80 & 85 & 82 & 82.33 & 2.52 \\
\hline 5 & Plant height at the time of fertilizer application, mm & 150 & 155 & 160 & 155 & 5 \\
\hline 6 & No. of tiller / plant & 13 & 12 & 14 & 13 & 1 \\
\hline 7 & Per cent plant damage, $\%$ & 3.5 & 4.5 & 5 & 4.33 & 0.76 \\
\hline
\end{tabular}

\section{Fertilizer application rate}

The machine was evaluated to apply the calibrated quantity of fertilizer i.e. $130.4 \mathrm{Kg} / \mathrm{ha}$. This resulted application of nitrogen at the rate of $60 \mathrm{~kg} / \mathrm{ha}$. The mean discharge rate of fertilizer was $100.00 \mathrm{~kg} / \mathrm{ha}$ is shown in Table 12 . It was due to application of fertilizer in four rows only as the two outside furrow openers were closed during the application of fertilizer in 5 rows bed planted wheat crop. During the field testing the average discharge of furrow opener varied from 0.106 to
$0.132 \mathrm{~kg}$ revolution. The difference in discharge rate during laboratory and field-testing was probably due to variation in tractor speed in field condition. The minimum and maximum discharge of fertilizer were $98.32 \mathrm{~kg} / \mathrm{ha}$ to $102.97 \mathrm{~kg} / \mathrm{ha}$. The coefficient of variation of fertilizer delivery from all tubes varied from 5.23 to $10.30 \%$. That machine applied the fertilizer at uniform rate as the $\mathrm{CV}$ was to \% with well acceptable limit for field experiment.

Table 12: Discharge rate of fertilizer under field condition at fertilizer application rate $130.4 \mathrm{~kg} / \mathrm{ha}$

\begin{tabular}{|c|c|c|c|c|c|c|c|c|c|c|}
\hline \multirow{2}{*}{ Test No } & \multicolumn{6}{|c|}{ Average discharge kg } & \multirow{2}{*}{ Application rate, $\mathrm{kg} / \mathrm{ha}$} & \multirow{2}{*}{ Mean discharge ratekg } & \multirow{2}{*}{ S. D. } & \multirow{2}{*}{ C.V. } \\
\hline & T1 & T2 & T3 & T4 & T5 & T6 & & & & \\
\hline \multicolumn{11}{|c|}{ Field testing } \\
\hline 1 & 0.00 & 0.113 & 0.127 & 0.115 & 0.118 & 0.00 & 100.42 & 0.1183 & 0.0061 & 0.0523 \\
\hline 2 & 0.00 & 0.107 & 0.121 & 0.106 & 0.131 & 0.00 & 98.72 & 0.1163 & 0.0119 & 0.1030 \\
\hline 3 & 0.00 & 0.113 & 0.126 & 0.114 & 0.132 & 0.00 & 102.97 & 0.1213 & 0.0086 & 0.0713 \\
\hline Mean & 0.00 & 0.1110 & 0.1246 & 0.1120 & 0.1266 & 0.00 & 100.70 & --- & --- & --- \\
\hline S. D. & 0.00 & 0.0034 & 0.0032 & 0.0051 & 0.0075 & 0.00 & 2.1391 & --- & 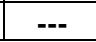 & $--\cdot$ \\
\hline
\end{tabular}

\section{Machine performance}

The developed machine was tested with a $35 \mathrm{hp}$ tractor for application of fertilizer at the depth of $150 \mathrm{~mm}$ on wheat crop sown on beds in 5 rows. During the field testing the operational speed and wheel slippage of machine were 3.7 $\mathrm{km} / \mathrm{h}$ and $4.69 \%$ respectively, show in Table 13.

Table 13: Details of fertilizer (granular urea) application in wheat crop

\begin{tabular}{|c|c|c|c|c|c|c|}
\hline \multirow{2}{*}{ S. No. } & \multirow{2}{*}{ Characters } & \multicolumn{3}{|c|}{ Particulars } & \multirow{2}{*}{ Mean } & \multirow{2}{*}{ S. D. } \\
\hline & & I & II & III & & \\
\hline 1 & Speed of operation $(\mathrm{km} / \mathrm{h})$ & 3.70 & 3.90 & 3.50 & 3.70 & 0.2 \\
\hline 2 & Wheel slippage (\%) & 4.71 & 4.23 & 5.14 & 4.69 & 0.46 \\
\hline 3 & Field capacity (ha/h) & 0.64 & 0.67 & 0.63 & 0.65 & 0.02 \\
\hline 4 & Field efficiency $\%$ & 78.90 & 81.22 & 80.2 & 80.11 & 1.16 \\
\hline 5 & Fuel consumption (lit/h) & 3.70 & 3.50 & 3.40 & 3.53 & 0.15 \\
\hline
\end{tabular}

The field capacity and field efficiency during fertilizer application in wheat crop are given in Table 14. The average field capacity and field efficiency of machine were $0.65 \mathrm{ha} / \mathrm{h}$ and $80.10 \%$ respectively. Average plant damage was $4.33 \%$ in the field during the application of fertilizer at the depth of $150 \mathrm{~mm}$ in wheat crop sown on beds.

\section{Crop yield parameters}

Yield of wheat crop under different method of application of granular urea is given in Table 14 and the grain yields were $5.72+$ /ha, $5.38+$ /ha and $6.1+$ /ha for fertilizer application through broadcast, foliar application and developed tractor operated fertilizer applicator, respectively. The tractor operated fertilizer applicator resulted $3 \%$ and $6.5 \%$ increased in yield as compared to broadcast and foliar application. Because ammonia did not evaporated to the atmosphere due to placing of fertilizer at a depth of $150 \mathrm{~mm}$ below the soil surface.

The saving of fertilizer placed in the soil by tractor operated fertilizer applicator was 33.33 and $16.6 \mathrm{~kg} / \mathrm{ha}$ as compared to broadcast and foliar application methods. The fertilizer use efficiency has increased significantly as the $46 \% \mathrm{~N} / \mathrm{ha}$ was use by the plant as compared to $61.33 \mathrm{~kg} / \mathrm{ha}$ and $38.33 \mathrm{~kg} / \mathrm{ha}$ in broadcast and foliar methods respectively. Nitrogen use efficiency in tractor operated fertilizer applicator was $33.33 \%$ and $16.6 \%$ higher than broadcast and foliar application methods. This showed that the tractor operated fertilizer applicator placed the granular urea very effectively below the $150 \mathrm{~mm}$ from the top soil surface near the root zone of plant that resulted increased biological yield of crop and reduced the quantity of fertilizer application and emission of $\mathrm{N}$ to the atmosphere.

Table 14: Wheat yields and Straw yields in different method of granular urea application

\begin{tabular}{|c|c|c|c|c|c|c|c|c|c|c|}
\hline \multirow{2}{*}{$\begin{array}{l}\text { S. } \\
\text { No. }\end{array}$} & \multirow{2}{*}{$\begin{array}{c}\text { Method of granular urea application in wheat } \\
\text { crop }\end{array}$} & \multirow{2}{*}{$\begin{array}{c}\text { Quantity of } \\
\text { fertilizer, kg/ha }\end{array}$} & \multicolumn{3}{|c|}{ Grain Yield kg/ha } & \multirow{2}{*}{$\begin{array}{l}\text { Mean } \\
\text { kg/ha }\end{array}$} & \multicolumn{3}{|c|}{ Straw yield kg/ha } & \multirow{2}{*}{$\begin{array}{l}\text { Mean } \\
\text { kg/ha }\end{array}$} \\
\hline & & & $\mathbf{I}$ & II & III & & $\mathbf{I}$ & II & III & \\
\hline 1 & Broadcast $(\mathrm{kg})$ & 133.33 & 5920 & 5610 & 5640 & 5723.33 & 1633 & 15380 & 15750 & 15820.00 \\
\hline 2 & Foliar application $(\mathrm{kg})$ & 83.33 & 5260 & 5670 & 5200 & 5376.67 & 1519 & 1673 & 15770 & 15896.67 \\
\hline 3 & Fertilizer application $(\mathrm{kg})$ & 100.00 & 6000 & 5670 & 6410 & 6026.67 & 169 & 1564 & 16940 & 16500.00 \\
\hline
\end{tabular}


Straw yield of wheat crop under different method of application of granular urea is given in Table 14 and the straw yields were $15820 \mathrm{~kg} / \mathrm{ha}, 15896.67 \mathrm{~kg} / \mathrm{ha}$ and $16500 \mathrm{~kg} / \mathrm{ha}$ for fertilizer application through broadcast, foliar application and developed fertilizer applicator, respectively. The tractor operated fertilizer applicator resulted $6.8 \%$ and $6 \%$ increased in yield in straw as compared to foliar application and broadcast methods. It was due placing of fertilizer at a depth of $150 \mathrm{~mm}$ below the soil surface near the root zone of plants that prevented the evaporation of ammonia to the atmosphere and increased the utilization of $\mathrm{N}$ efficiently and effectively by the plants.

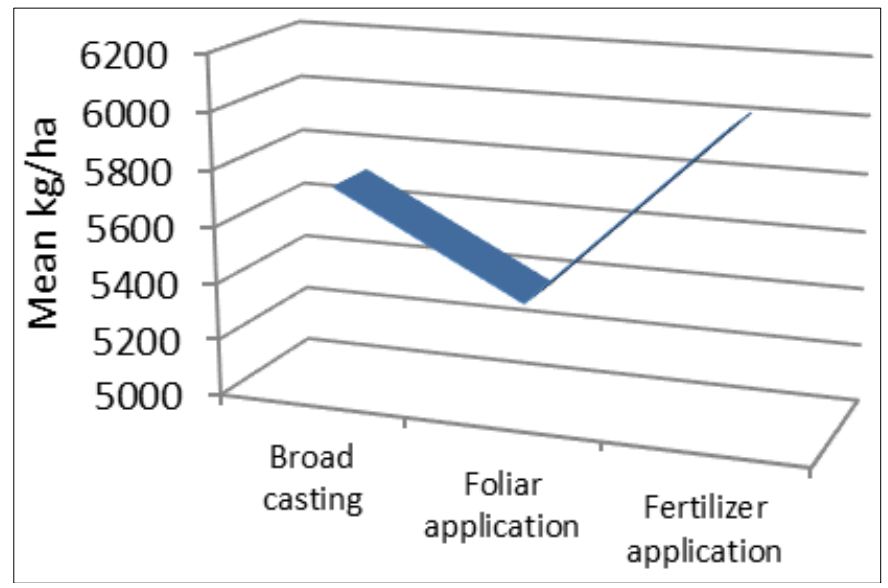

Fig 2: Grain yields in different method of granular urea application

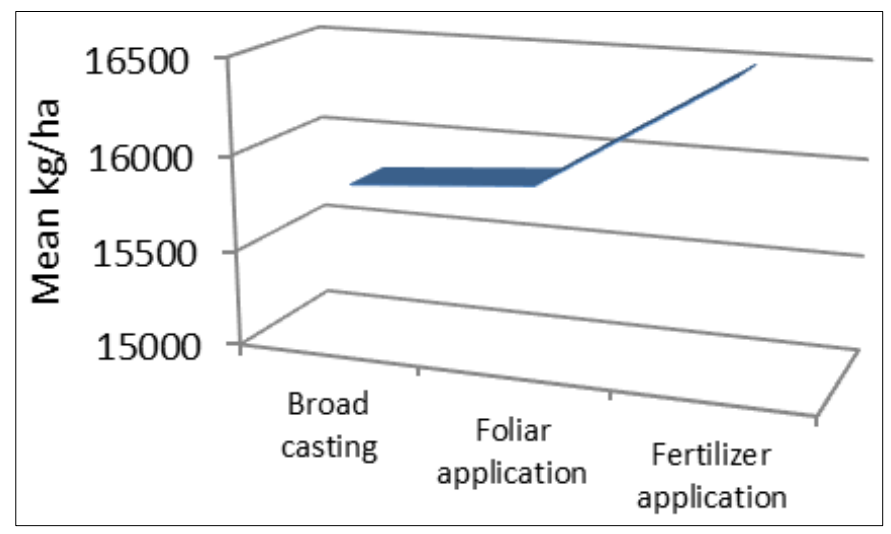

Fig 3: Straw yields in different method of granular urea application

\section{Cost Economics}

The cost of application in foliar application of granular urea in top dressing by labours was Rs. 270/ha, Rs. 540/ha and the cost operation for tractor operated fertilizer was applicator of six rows has been estimated as Rs. 650/ha. The savings in granular urea were 8.74 and $2.76 \mathrm{~kg} / \mathrm{ha}$ by using the tractor operated fertilizer applicator as compared to broadcast and foliar application. This resulted saving of fertilizer of Rs. 721 and Rs. 216/ha as compared to there to method. Thus tractor operated fertilizer applicator resulted saving of Rs 341 and Rs $611 /$ ha. For the application of fertilizer at $150 \mathrm{~mm}$ below the soil surface as compared to broadcast and foliar application methods.

\section{Conclusion}

The application of granular urea on bed planted 5 rows wheat crop. Properties of granular urea were studied included size and shape (linear dimension), density, sphericity, fertilizer mass (weight) of hundred particles. The fertilizer applicator was calibrated for granular urea application rate of $60.2 \mathrm{~kg} / \mathrm{ha}$ to $130.4 \mathrm{~kg} / \mathrm{ha}$. The developed machine was tested in the field for application of granular urea/nitrogen at the rate of 130 $\mathrm{kg} / \mathrm{h}$ (60 kg N/ha) on bed planted wheat crop. The developed machine operated with a $35 \mathrm{hp}$ tractor performed very and efficiently for the placement of urea at the depth of $150 \mathrm{~mm}$ below the soil surface. It saved the fertilizer, fuel, time and resulted increased in yield, use efficiency of nitrogen, saving in fertilizer by placing near the root zone of wheat plant below the soil. It prevented the loss of nitrogen to atmosphere. The savings in granular urea was $8.74 \mathrm{~kg} / \mathrm{ha}$ by using the tractor operated fertilizer applicator as compared to broadcasting. The machine has also resulted saving in cost of operation Rs. 341/ha and Rs. 611/ha as compared to broadcast and foliar application methods including cost of fertilizer. The major conclusion of the study is reported below.

1. The physical properties of fertilizer (granular urea) size, shape, sphericity, density and hundred particles weight were observed. The mean values for size shape (sphericity), bulk density and hundred particle weight were $1.85 \pm 0.4,0.99 \pm 0.004,0.76 \pm 0.0011$, and $0.8 \pm$ 0.6 with $95 \%$ confidence limit at moisture content of $18.7 \%$

2. Under laboratory condition during the calibration, the fertilizer applicator gave 66.73 and $131.55 \mathrm{~kg} / \mathrm{ha}$ of granular urea with $\mathrm{CV}$ of, 0.10 and 0.033 respectively. Thus showed that machine uniform fertilizer application rate.

3. The developed tractor operated fertilizer applicator has applied the granular urea at the rate of $100 \mathrm{~kg} / \mathrm{ha}$ in 4 rows between the 5 rows wheat crop planted on bed. Average depth of application of urea was $150 \mathrm{~mm}$ below the soil surface on wheat crop planted on beds. Also machine worked satisfactorily for applying the fertilizer at different depth (50-300mm).

4. The speed of operation and slippage of developed machine in the field were $3.70 \mathrm{~km} / \mathrm{h}$ and $4.69 \%$ during the field operation.

5. The field capacity and field efficiency of machine were $0.65 \mathrm{ha} / \mathrm{h}$ and $80.10 \%$ during the fertilizer application on 5 rows bed planted wheat crop.

6. The tractor operated fertilizer applicator resulted $3 \%$ and $6.5 \%$ increased in yield as compared to broadcast and foliar application methods. Increased in yield of crop straw were $6 \%$ and $6.8 \%$ as compared to foliar application and broadcast methods.

7. The savings in granular urea were 8.74 and $2.76 \mathrm{~kg} / \mathrm{ha}$ by using the tractor operated fertilizer applicator as compared to broadcast and foliar application. This gave saving of Rs 341 and Rs 611/ha for tractor fertilizer applicator as compared to broadcast and foliar application methods.

\section{Reference}

1. Bansal RK, Thierstein GE. Metering granular fertilizer with an oscillatory mechanism. J Agric. Engg. 1984; 21(1 and 2):1-8.

2. Blackshaw RE, Molnar LJ, Janzen HH. Nitrogen fertilizer timing and application method affect weed growth and competition with spring wheat. Weed Sci. 2004; 52:614-622.

3. Chandy KT. Agricultural \& Environmental Education. Fertilizers Application \& Efficient Use Booklet No, 1978 23.

4. Davidson EA, Swank WT, Perry T0. Distinguishing between nitrification and denitrification as sources of 
gaseous nitrogen production in soil. Appl. Environ. Microbiol. 1986; 52:1287-1292.

5. Desai RM, Bhatia CR. Nitrogen uptake and nitrogen harvest index in durum wheat cultivars varying in their grain protein concentration. Euphytica. 1978; 27:561566.

6. Dibb DW, Fixen PE, Stauffer MD. Fertilizer Use Efficiency: The North American Experience Better Crops. 2003; 87(3):3.

7. Fertilizer Manual United Nations Industrial Development Organization, International Fertilizer Development Center, 1998.

8. Fiez TE, Miller BC, Pan WL. Assessment of spatially variable nitrogen fertilizer management in winter wheat. Journal of Production Agriculture. 1994; 7:86-93.

9. Godwin RJ, Spoor G. The design and performance for the subsoil placement of fertilizer. Paper No., 1981, 81-1091.

10. http://www.ehow.comPhysical Properties of Fertilizers eHow.com

11. Kamath MB. (IARI) Fertilizer in agriculture development page, 1987, 117.

12. Kamath MB. (IARI) Fertilizer in agriculture development page, 1983, 130.

13. Lan Y, Zhang SW, Li WC, Hoffmann, Ma C. Variable rate fertilization for maize and its effects based on the site-specific soil fertility and yield". Agricultural Engineering International: the CIGR journal. Manuscript IT 08 002, 2008, 10.

14. Rowse HR, Stone DA. Deep cultivation of a sandy loam. Effects on growth, yield and nutrient content of potatoes, broad beans, summer cabbage and red beet. Soil and Tillage Research. 1980; 1(1):57-68.

15. Tandon HLS. Fertilizer guide, $.2^{\text {nd }}$ edn fertilizer development and consultations organization, New Delhi, 1994, 155.

16. Wuest SB, Cassman KG. Fertilizer-nitrogen use efficiency of irrigated. Wheat. Uptake efficiency of preplant versus late-season application. Agron. J. 1992; 84:682-688.

17. Yang CJH, Everitt, Bradford JM. Comparisons of uniform and variable rate nitrogen and phosphorus fertilizer applications for grain sorghum. Transactions of the American Society of Agricultural Engineers. 2001; 44(2):201-209.

18. Zhigulev AK. Effect of foliar application of nitrogen fertilizer on yield and quality of winter wheat grain. Agrokhemiya. 1992; (3):3-9. 